\title{
THE POSITION OF CYANOBACTERIA IN THE WORLD OF PHOTOTROPHS.
}

\author{
by \\ ROGER Y. STANIER \\ Département de Biochimie et Génétique Microbienne \\ 28, rue du Dr Roux, 75015 Paris, France \\ Emil Chr. HANSEN lecture delivered at the Carlsberg Laboratory \\ Centennial and the Inauguration of the Carlsberg Research Center on September 28th, 1976
}

Key words: prokaryotic photosynthetic apparatus; obligate photoautotrophy; oxidative and reductive pentose phosphate cycles; nitrogen fixation; oxygenic photosynthesis; facultative anoxygenic photosynthesis; cyanobacterial ecology; cyanobacterial developmental patterns

Recent advances in our knowledge of the biological properties of the cyanobacteria (former „blue-green algaex) are reviewed. The subjects discussed include: cyanobacterial cell structure and development; comparative aspects of photosyntetic structure and function in prokaryotes; carbon metabolism and its relation to obligate photoautotrophy; and special properties of cyanobacteria that are of ecological significance (temperature relationships, nitrogen fixation and facultative anoxygenic photosynthesis).

\section{INTRODUCTION}

The largest evolutionary discontinuity among contemporary organisms lies at the cellular level; it permits us to distinguish two biological superkingdoms, eukaryotes and prokaryotes $(46,43)$. The recognition of this fact is quite recent, since the differences between the eukaryotic and the prokaryotic cell could not be rigorously formulated prior to 1960. A major technical advance, the application of electron microscopy to the study of biological fine structure, was necessary to reveal the nature and extent of the structural differences between prokaryotic and eukaryotic cells; and the deep- seated functional differences between the two kinds of cells could be appreciated only after the molecular biological revolution.

In addition to the organisms long recognized as bacteria, the superkingdom of prokaryotes includes a large and widely distributed group of phototrophic organisms, the cyanophytes or blue green algae. They can be defined as microorganisms that harbor, within a typically prokaryotic cell, a photosynthetic apparatus similar in structure and function to that located in the chloroplast of phototrophic eukaryotes. Their traditional classification as algae was, accordingly, based on the resemblances be- 


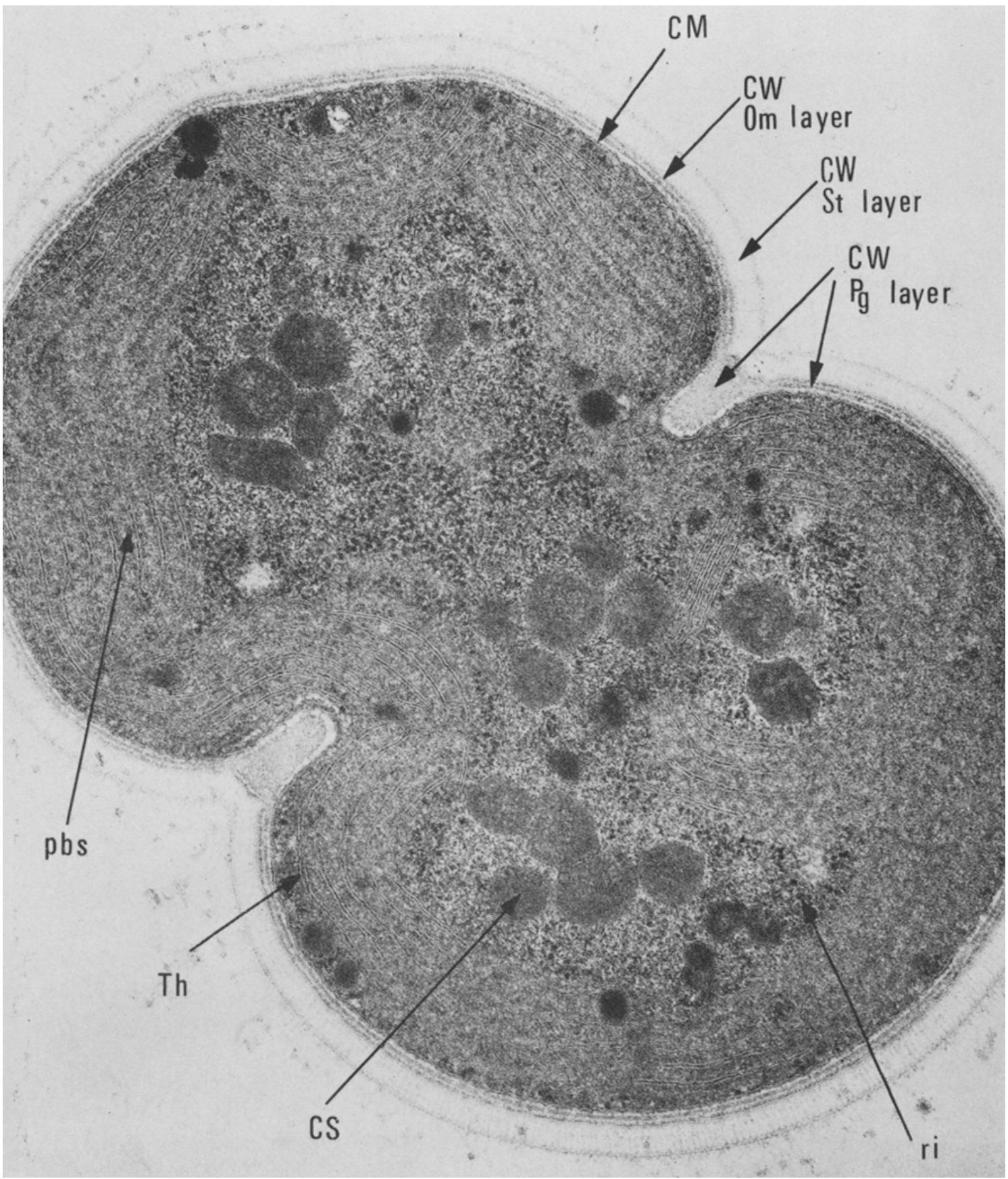

Figure 1. Thin section of a unicellular cyanobacterium, Synechocystis ATCC 27178, in the course of division. $60,000 \times$. The cell membrane $(\mathrm{CM})$ is surrounded by a wall composed of three layers: the peptidoglycan $(\mathrm{Pg})$ layer, the outer membrane $(\mathrm{Om})$ layer, both universal in cyanobacteria; and an additional structured (St) layer. The regularly spaced thylakoids (th) bear rows of phycobilisomes (pbs), attached to both surfaces. Cs, carboxysome; ri, $70 \mathrm{~S}$ ribosome. 


\section{R. Y. STANIER: Cyanobacteria}

tween the cyanophytan cell and one constituent of the algal cell, its chloroplast. These organisms are in reality bacteria, and I shall hereafter refer to them collectively as cyanobacteria.

The cyanobacteria differ from the two other groups of phototrophic prokaryotes, which have always been classified among the bacteria -namely, purple and green bacteria - in many respects: the mechanism of photosynthesis; the fine structure and chemical composition of the photosynthetic apparatus; nutritional requirements and growth physiology.

Fifteen years ago, when we began to work on cyanobacteria, these organisms were still construed as algae, and their study was largely conducted, as it always had been, by phycologists, with a heavy emphasis on descriptive taxonomy and ecology. It was commonly believed that the isolation of pure cultures is exceptionally difficult, even though M. B. ALLEN (1) had made a promising start on this technical problem about 1950: indeed, most of the pure strains then in existence had been isolated by her. Accordingly, much of our initial work was directed to the isolation and purification of additional members of this group (47), an essential prerequisite for comparative experimental studies. The news that these organisms are really bacteria has spread, thus encouraging other microbiologists to take up work on cyanobacteria. More significant information about their biological properties has emerged in the past decade than in the preceding century. Some of these recent advances will be reviewed here.

\section{CELL STRUCTURE AND DEVELOPMENT}

\subsection{Organization of the cyanobacterial cell.}

Like the other photosynthetic prokaryotes, cyanobacteria belong to the major sub-class of Gram negative bacteria, an assemblage now no longer defined by the staining reaction of the cell, but rather by the fine structure and molecular composition of its wall. The cyanobacterial cell wall contains at least two structurally distinct layers (fig. 1). The relatively thin and electron-dense innermost layer is composed of peptidoglycan (18). It is surrounded by a layer with the dimensions and fine structure of a unit membrane, containing proteins and lipopolysaccharides (16). These two wall layers, common to all Gram negative bacteria, are accompanied in many cyanobacteria by additional wall layers, an example of which is evident in figure 1 .

The only form of cellular locomotion in cyanobacteria is gliding movement, widespread but not universal. A layer of fibrils, intercalated between the two layers of the Gram negative cell wall, has recently been demonstrated in some gliding cyanobacteria (24), and may possibly be the organelle responsible for this type of movement.

The cell membrane, usually of simple contour, is closely appressed to the peptidoglycan wall layer. The most conspicuous internal structures of the cell are the regularly spaced photosynthetic thylakoids, which occupy much of the cytoplasmic region, and bear attached to their outer surfaces disc-shaped structures about 40 $\mathrm{nm}$ in diameter, known as phycobilisomes. The phycobilisome is a light-harvesting organelle, and contains the cellular complement of phycobiliproteins, the major components of the cyanobacterial light-harvesting pigment antenna (21). The nucleoplasm has a typically prokaryotic fine structure. The cytoplasm contains a comparatively sparse population of $70 \mathrm{~S}$ ribosomes, a reflection of the low growth rates characteristic of most cyanobacteria.

Two classes of inclusions characteristic of cyanobacteria are carboxysomes and cyanophycin granules. The former - polyhedral bodies bounded by a thin, non-unit membrane - occur in many other prokaryotes which use $\mathrm{CO}_{2}$ as their major carbon source. They have been recently isolated from a chemoautotroph, Thiobacillus neapolitanus (38), and shown to be filled with closely packed molecules of carboxydismutase, the enzyme responsible for $\mathrm{CO}_{2}$ fixation in autotrophs. The carboxysome might be considered the prokaryotic counterpart of the pyrenoid.

Cyanophycin granules (27) have been detected only in cyanobacteria. The recent isolation of these granules (39) has led to the interesting discovery that they are composed of a branched polypeptide which contains only two amino 

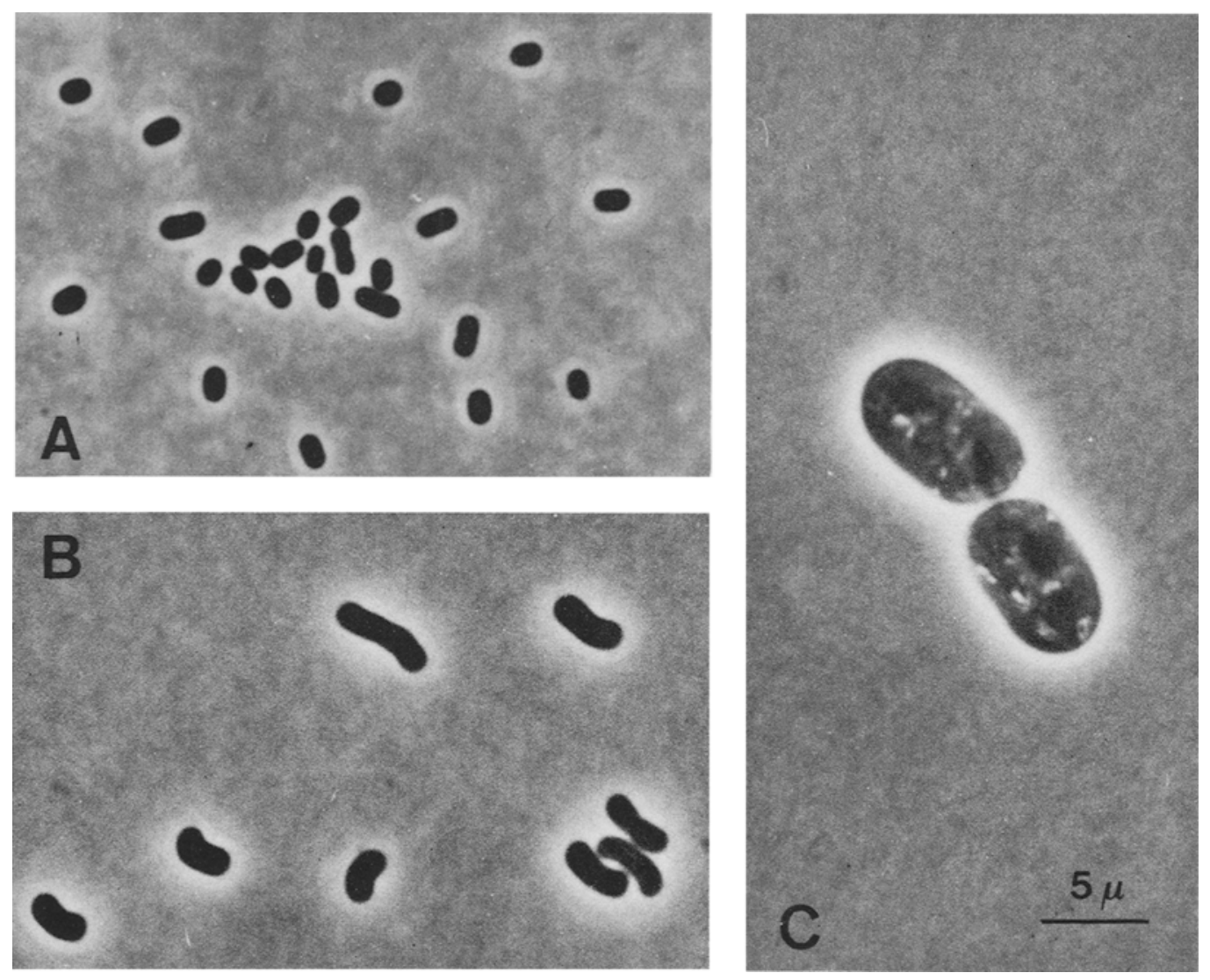

Figure 2. Rod-shaped unicellular cyanobacteria of the genus Synechococcus. Phase contrast, 2000 x. A, ATCC 27194; B, ATCC 27145; C, ATCC 29534.

acids: a polyaspartic acid core, bearing lateral arginyl residues (40). This material accumulates in the cell as cultures approach the stationary phase, and probably serves as a nitrogen reserve.

\subsection{Patterns of development}

The simplest cyanobacteria are unicellular rods or cocci, which reproduce by binary fission (figs. 2 and 3). A few unicellular cyanobacteria (fig. 4) reproduce by budding (51), a variant of binary fission which also occurs in many other bacterial groups (44).

The pleurocapsalean cyanobacteria have a remarkable developmental cycle, which is illustrated in figure 5 for one of the simplest representatives, Democarpa (52). A small reproductive cell, 2-3 $\mu \mathrm{m}$ in diameter, enlarges without cell division into a vegetative cell which can attain a diameter of $20-30 \mu \mathrm{m}$, this development being accompanied by the formation and progressive thickening of a fibrous outer wall layer. A rapid series of cell divisions unaccompanied by growth then takes place within the fibrous wall layer, which breaks open to release as many as 1000 reproductive cells. In Dermocarpa, this process of multiple fission is the only mode of cell division. In other pleurocapsalean cyanobacteria, exemplified by Pleurocapsa (fig. 6 ), enlargement of the reproductive cell is followed by a series of binary fissions, to produce an aggregate of vegetative cells, held together by the contiguous fibrous outer wall layers; some (or all) of the vegetative cells then undergo multiple fission and release small reproductive cells. 

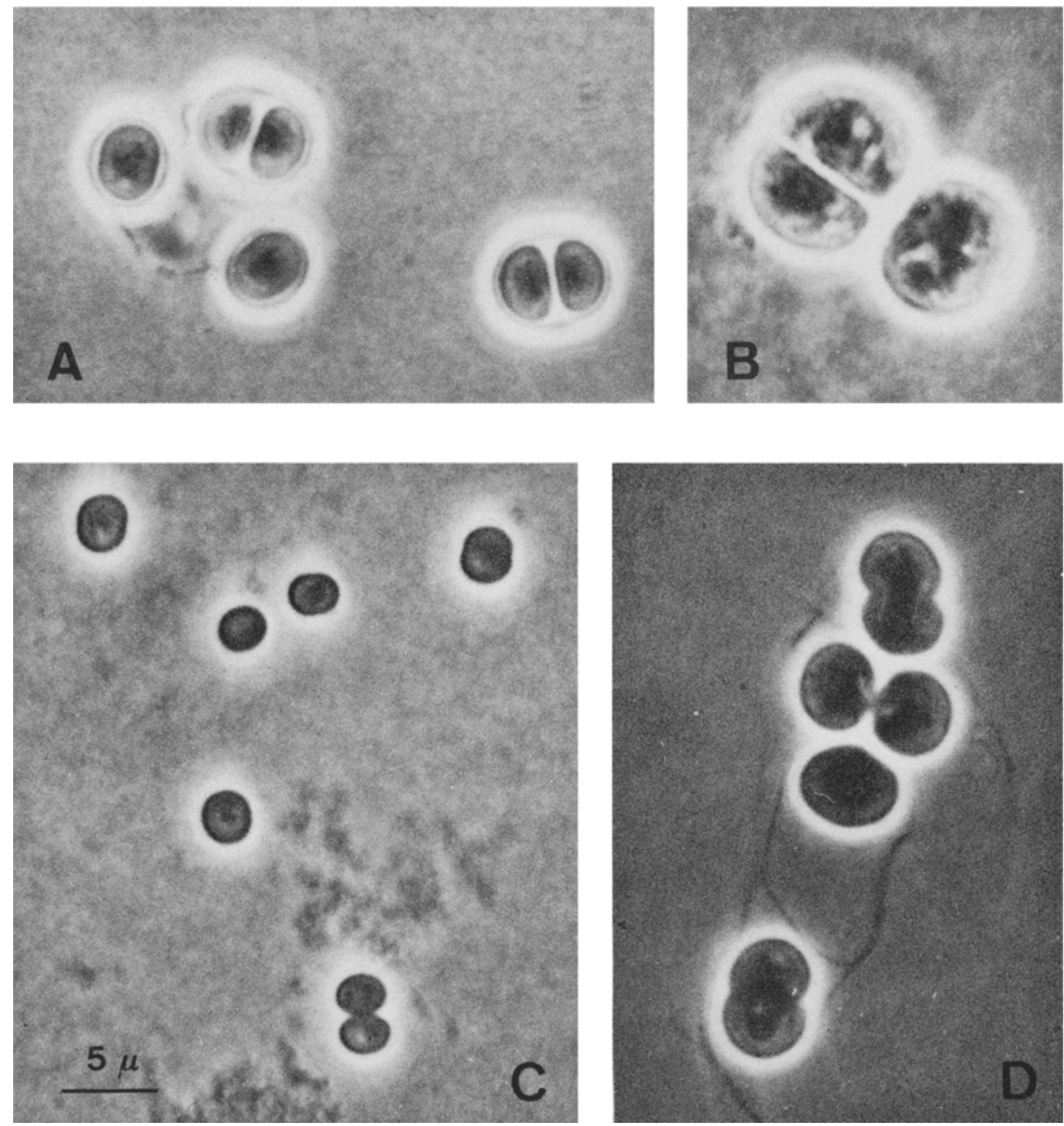

Figure 3. Coccoid unicellular cyanobacteria of the genera Gloeocapsa $(A, B)$, the cells of which are enclosed by sheaths, and Synechocystis (C, D), the cells of which are not ensheathed. Phase contrast, 2000 x. A, ATCC 29159; B, ATCC 29113; C, ATCC 27171; D, ATCC 27819.

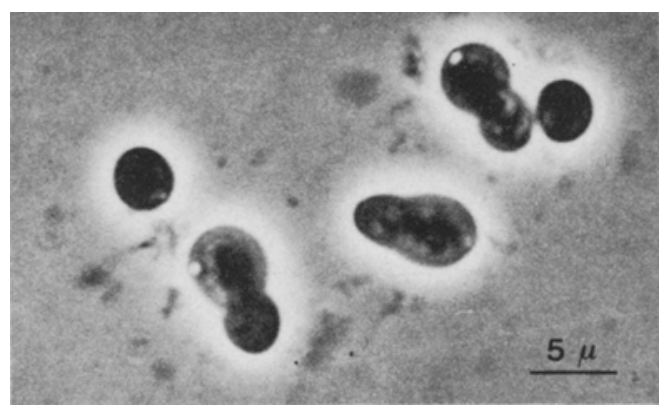

Many cyanobacteria have a filamentous structure. The filament of cells, or trichome, elongates by intercalary divisions and reproduces by breakage. In oscillatorian cyanobac-

Figure 4. A unicellular budding cyanobacterium, Chamaesiphon ATCC 29397. Phase contrast, $2000 \mathrm{x}$. Three cells with polar buds, and two recently released small daughter cells. 

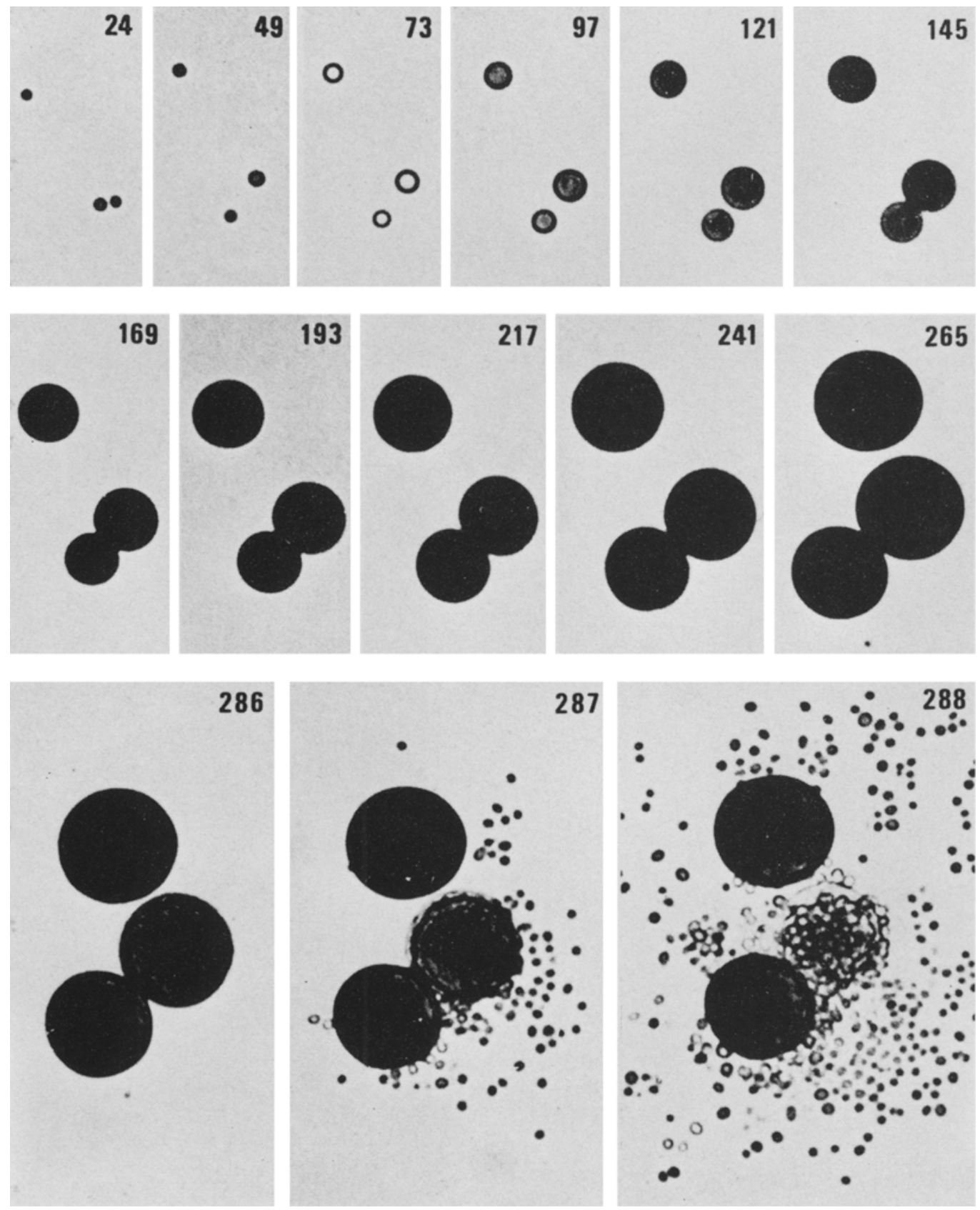

Figure 5. Dermocarpa ATCC 29368. $500 \mathrm{x}$. Time lapse photomicrographs of the growth of three vegetative cells over a period of $288 \mathrm{hr}$. One cell has undergone multiple fission, and released small daughter cells.

teria (fig. 7) the trichome is an unbranched chain, composed only of vegetative cells. Other filamentous cyanobacteria can undergo cellular differentiation, some vegetative cells in the tri- chome being converted into non-reproductive cells with a special physiological function, known as heterocysts. Certain heterocystous cyanobacteria also form thick-walled resting 
Figure 6. Pleurocapsa ATCC 29388. $1000 x$. An aggregate of vegetative cells, some of which have undergone multiple fission. The arrow points to a small daughter cell.

cells known as akinetes, which likewise differentiate from vegetative cells of the filament (fig. 8).

Cell divisions in all oscillatorian and many heterocystous cyanobacteria occur in only one plane, at right angles to the long axis of the trichome. However, some members of the latter group have a more complex pattern of vegetative growth. As the trichome develops, it becomes branched and in part multiseriate, a consequence of changes in the plane of division of some of the constituent cells (fig. 9).

\section{STRUCTURE AND FUNCTION OF THE PROKARYOTIC \\ PHOTOSYNTHETIC APPARATUS}

As already mentioned, there is a dichotomy among phototrophic prokaryotes with respect to the mechanism of photosynthesis. In cyanobacteria, as in phototrophic eukaryotes, photosynthesis is oxygenic: molecular oxygen is a major metabolic product. In purple and green bacteria, on the other hand, photosynthesis is anoxygenic. This gross metabolic difference is the expression of a profound difference in the underlying photochemical mechanisms.

\subsection{A comparative analysis of photosynthetic function}

The photosynthetic apparatus can be dissected experimentally into three major components, which are closely integrated both functionally and structurally (fig. 10). These are: an antenna of light-harvesting pigments; a limited number of photochemical reaction centers, which always contain chlorophylls in a special state; and an electron transport chain. The re-

Figure 7. Three filamentous cyanobacteria of the genus Oscillatoria. 500 x. A, ATCC 29209; B, ATCC 29081; C, A TCC 29169.
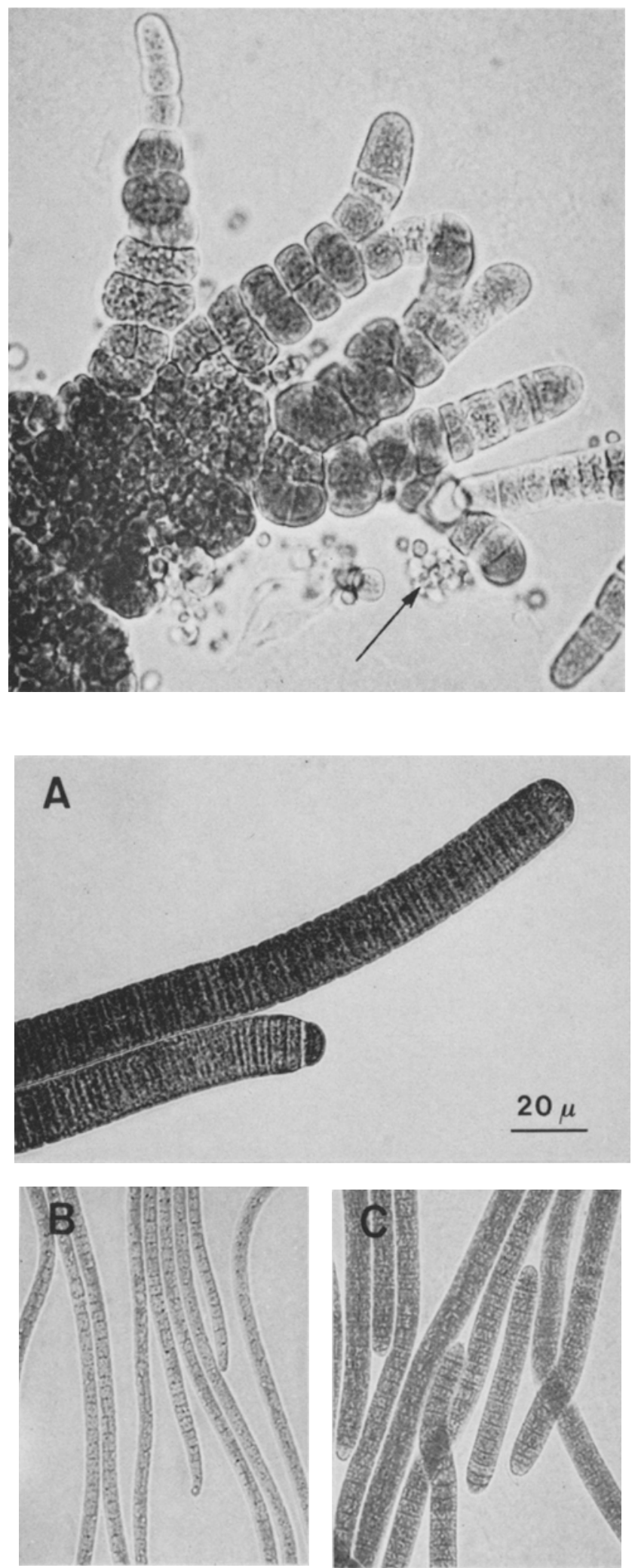


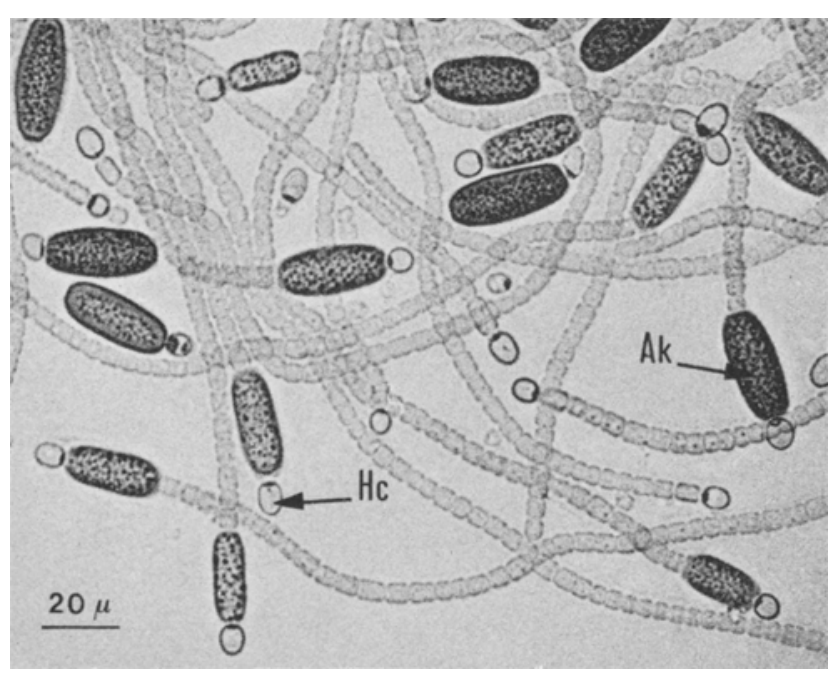

Figure 8. Cylindrospermum ATCC 29535, a cyanobacterium which produces both heterocysts $(\mathrm{HC})$ and akinetes (AK). $500 \mathrm{x}$. In this genus, the heterocysts are terminal, and the akinetes sub-terminal. action centers and the carriers of the electron transport system are always incorporated into a unit membrane. In most phototrophs, this is also the site of the light-harvesting pigments. However, part or all of these pigments may be located in peripheral structures, attached to the unit membrane, as exemplified by the phycobilisomes which contain the major cyanobacterial light-harvesting pigments. Light energy absorbed by the antenna pigments is channelled by radiationless transfer to a reaction center, where a charge separation is effected by ejection of an electron from the reaction center chlorophyll. This initiates a cyclic electron flow in the associated photosynthetic electron transport chain, coupled with the synthesis of ATP. The light-mediated synthesis of ATP is the common denominator of all modes of photosynthesis. In the anoxygenic photosynthesis performed by purple and green bacteria, it is the sole chemical consequence of light absorption (fig. 11). In oxygenic photosynthesis, however, the

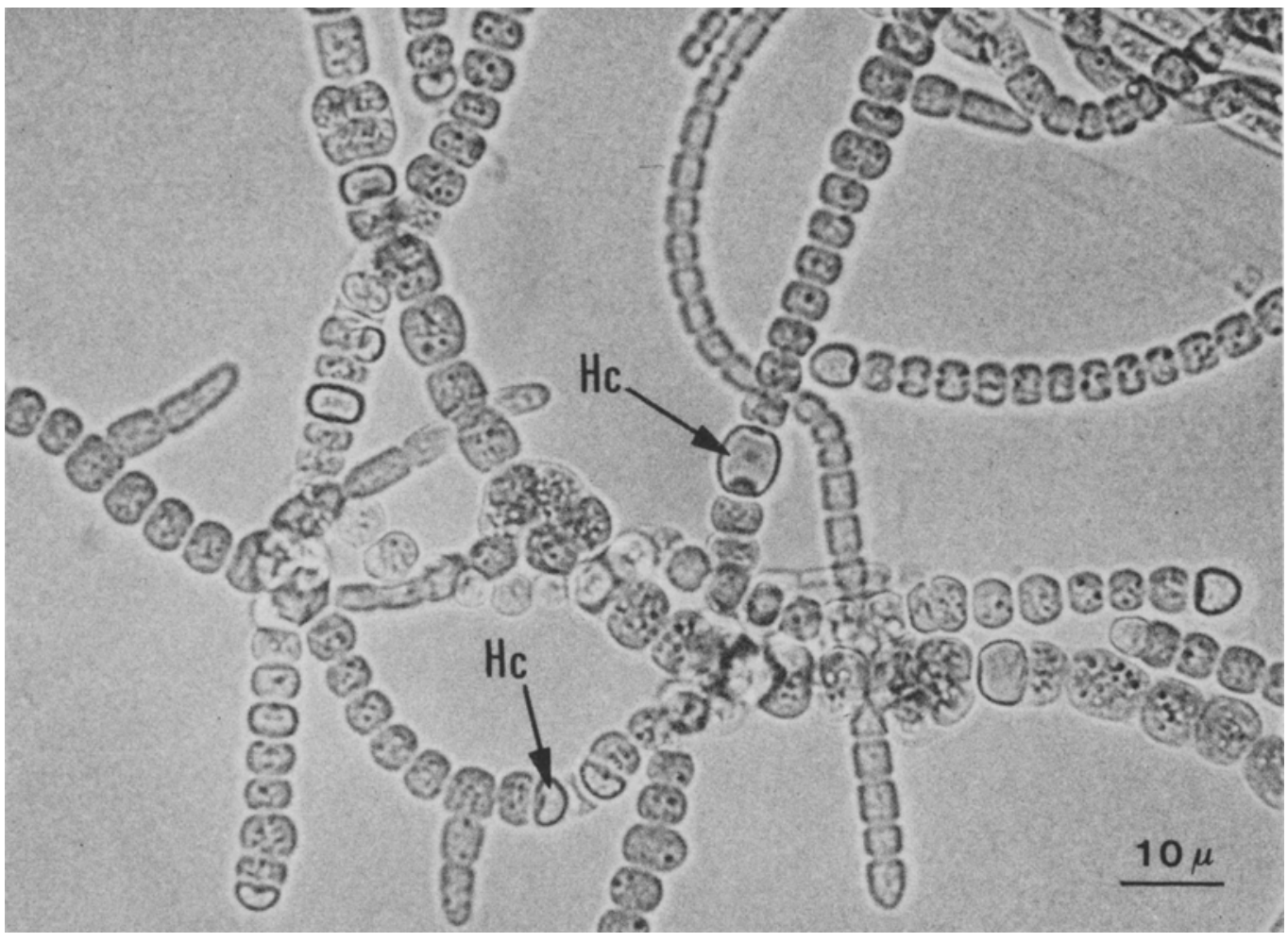

Figure 9. Fischerella ATCC 29538, a heterocystous cyanobacterium which forms branched and in part multiseriate trichomes. $500 \mathrm{x}$. HC, heterocyst. 


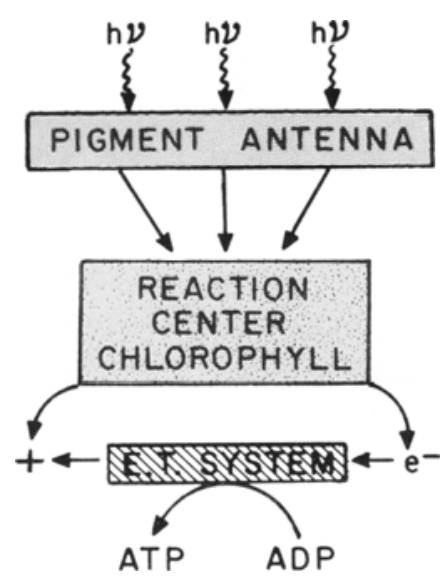

Figure 10. A schematic diagram to show the functions of the three components of a photosynthetic apparatus.

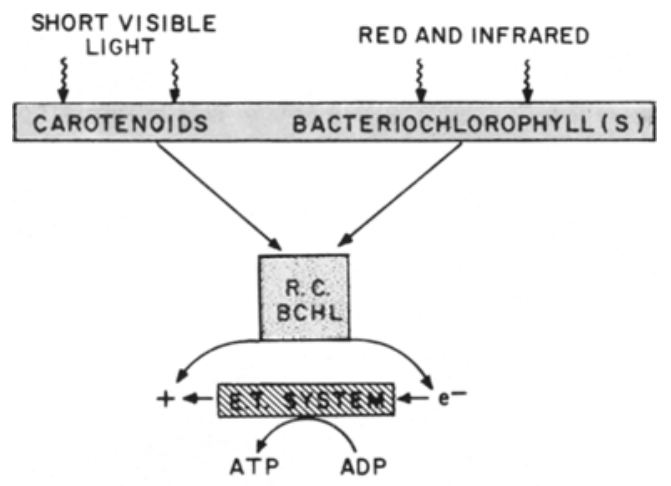

FUNCTION OF THE PHOTOSYNTHETIC APPARATUS IN PURPLE AND GREEN BACTERIA

Figure 11. A schematic diagram of the function of the photosynthetic apparatus of purple and green bacteria, RC BCHL, reaction center bacteriochlorophyll.

chemical consequences of light absorption are considerably more complex, as a result of the fact that the photosynthetic apparatus contains two different types of reaction centers, known as type I and type II reaction centers (fig. 12). The type I reaction center, like the single reaction center associated with the performance of anoxygenic photosynthesis, can mediate ATP synthesis by cyclic electron flow. The specific function of the type II center is to mediate the photolysis of water. The two reaction centers are functionally interconnected through the electron transport chain. If both are simultaneously excited, a non-cyclic electron flow occurs, linking the oxidation of water at reaction center II with the reduction of pyridine nucleotide at reaction center $I$, and accompanied by ATP synthesis. In oxygenic photosynthesis, energy transfer from the light-harvesting pigment antenna to the two reaction centers is to some extent compartmentalized. For example, in cyanobacteria, the energy of light quanta harvested by chlorophyll $a$ is largely

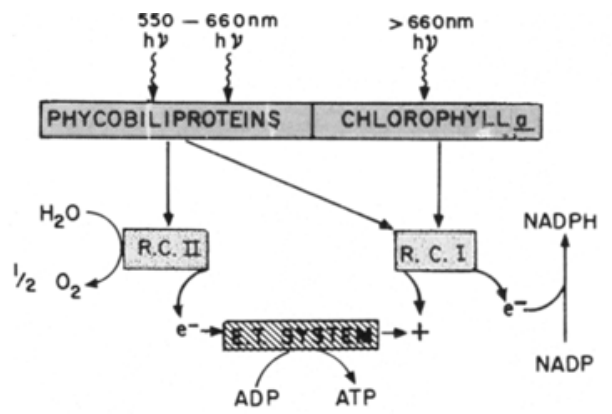

NON-CYCLIC ELECTRON FLOW IN CYANOBACTERIA AND RHODOPHYTAN CHLOROPLASTS.

Figure 12. A diagram of the cyanobacterial photosynthetic apparatus, showing non-cyclic electron flow. $R C$, reaction center.

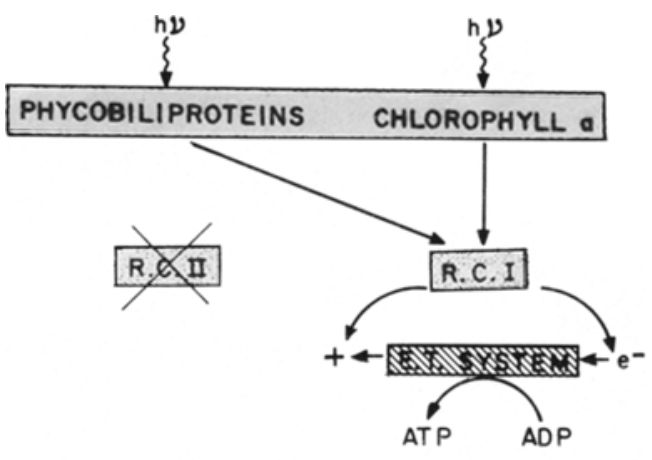

FUNCTION OF THE CYANOBACTERIAL PHOTOSYNTHETIC APPARATUS WHEN R.C.II FUNCTION IS ABOLISHED (e.g., by DCMU or $\mathrm{H}_{2} \mathrm{~S}$ )

Figure 13. Operation of the cyanobacterial photosynthetic apparatus when reaction center II function is selectively inhibited, for example by treatment with DCMU. 


\section{R. Y. STANIER: Cyanobacteria}

channelled to reaction center $I$, whereas the energy of light quanta harvested by phycobiliproteins is transmitted to both reaction centers (25).

Photosynthetic energy conversion can still proceed in cyanobacteria if reaction center II activity is destroyed, for example, by treatment with an appropriate concentration of the herbicide DCMU (42). Under these special circumstances, photosynthesis becomes anoxygenic, photophosphorylation occurring though cyclic electron flow associated with reaction center I (fig. 13).
3.2. The biosynthetic consequences of oxygenic and anoxygenic photosynthesis.

What are the consequences for biosynthesis of the chemical differences between oxygenic and anoxygenic photosynthesis? Most, if not all, phototrophs can synthesize organic cell material from $\mathrm{CO}_{2}$, a process that requires an input both of ATP and of reducing power, the latter in the form of reduced pyridine nucleotide. Both are provided by the reactions of oxygenic photosynthesis (25). However, anoxygenic photosynthesis provides only ATP (42). Hence the synthesis of cell material from $\mathrm{CO}_{2}$ by purple

Table I

The chemical differences between oxygenic and anoxygenic photosynthesis

\begin{tabular}{|c|c|c|c|}
\hline & $\begin{array}{l}\text { Source of } \\
\text { carbon }\end{array}$ & $\begin{array}{l}\text { Source of } \\
\text { ATP }\end{array}$ & $\begin{array}{l}\text { Source of } \\
\text { reducing power }\end{array}$ \\
\hline $\begin{array}{l}\text { Purple and } \\
\text { green bacteria }\end{array}$ & $\begin{array}{l}\mathrm{CO}_{2} \\
\text { Organic } \\
\text { compounds }\end{array}$ & $\begin{array}{l}\text { Photochemical } \\
\text { Photochemical }\end{array}$ & $\begin{array}{l}\mathrm{H}_{2} \mathrm{~S}, \mathrm{H}_{2} \\
\text { (enzymatic) } \\
\text { Not required }\end{array}$ \\
\hline $\begin{array}{l}\text { Cyanobacteria } \\
\text { and chloroplasts }\end{array}$ & $\mathrm{CO}_{2}$ & Photochemical & $\begin{array}{l}\mathrm{H}_{2} \mathrm{O} \\
\text { (photochemical) }\end{array}$ \\
\hline
\end{tabular}

Table II

Comparative chemistry of the photosynthetic apparatus

\begin{tabular}{|c|c|c|c|}
\hline & $\begin{array}{l}\text { Light-harvesting } \\
\text { pigments }\end{array}$ & $\begin{array}{l}\text { Principal } \\
\text { electron carriers }\end{array}$ & $\begin{array}{l}\text { Membrane glycolipids } \\
\text { (diglycerides) }\end{array}$ \\
\hline $\begin{array}{l}\text { Purple } \\
\text { bacteria }\end{array}$ & \multirow{2}{*}{$\begin{array}{l}\text { Bacteriochlorophylls; } \\
\text { group-specific } \\
\text { aliphatic or monocyclic } \\
\text { carotenoids }\end{array}$} & \multirow{2}{*}{$\begin{array}{l}\text { Bacterial }{ }_{\text {" ferredoxins; }} \\
\text { group-specific } \\
\text { quinones and } \\
\text { cytochromes }\end{array}$} & None \\
\hline $\begin{array}{l}\text { Green } \\
\quad \text { bacteria }\end{array}$ & & & Monogalactosyl- \\
\hline $\begin{array}{l}\text { Cyanobacteria and } \\
\text { rhodophytan chloroplast }\end{array}$ & $\begin{array}{l}\text { Chlorophyll a; } \\
\text { phycobiliproteins; } \\
\beta \text {-carotene and derivatives }\end{array}$ & \multirow{2}{*}{$\begin{array}{l}\text { Plant ferredoxin; } \\
\text { plastoquinone; } \\
\text { plastocyanin; } \\
\text { cytochrome f }\end{array}$} & \multirow{2}{*}{$\begin{array}{l}\text { Monogalactosyl-; } \\
\text { digalactosyl- } \\
\text { and sulfoquinovosyl- }\end{array}$} \\
\hline $\begin{array}{l}\text { Chlorophytan } \\
\text { chloroplast }\end{array}$ & $\begin{array}{l}\text { Chlorophylls } a \text { and } b \\
\beta \text {-carotene and derivatives }\end{array}$ & & \\
\hline
\end{tabular}


and green bacteria is dependent on the generation of reduced pyridine nucleotide by nonphotochemical means; specifically by the enzymatic oxidation of $\mathrm{H}_{2} \mathrm{~S}$, other reduced inorganic sulfur compounds, or molecular hydrogen. A suitable chemical electron donor is thus required by these phototrophs for the synthesis of cell material from $\mathrm{CO}_{2}$. Some purple and green bacteria can use organic compounds in place of $\mathrm{CO}_{2}$ as a source of carbon in the light: under these circumstances, biosynthesis is dependent only on an input of ATP, and the requirement for an inorganic electron disappears (45). These differences are summarized in Table I.

\subsection{Comparative anatomy of the prokaryotic pho-} tosynthetic apparatus.

The mechanistic dichotomy between oxygenic and anoxygenic photosynthesis is paralleled by differences in both the chemical composition and the fine structure of the photosynthetic apparatus. Major chemical differences exist with respect to the antenna pigments, the components of the electron transport system, and the lipids of the photosynthetic apparatus (Table II). The anatomical differences are equally striking (9). In purple bacteria (fig. 14) all elements of the photosynthetic apparatus are integrated into the cell membrane, which has a very complex topology (10). It is deeply infolded into the cytoplasm, and consequently has a very large area, this being the only physical means to accomodate a high level of light-harvesting pigments.

In green bacteria (fig. 15) the reaction centers and the electron transport system are located in the cell membrane, which has a simple topology (20): the antenna of light-harvesting pigments is adjacent to the membrane and is located in a series of cortical ovoid structures known as chlorobium vesicles (11).

Among cyanobacteria, the photosynthetic apparatus can assume two configurations (figs.

Figure 15. Thin section of the green bacterium, Chlorobium limicola. $C W$, cell wall, bearing pili $(P) . C M$, cell membrane. $\mathrm{CV}$, chlorobium vesicle. 135,000 x. Courtesy of Dr. Germaine Cohen-Bazire.

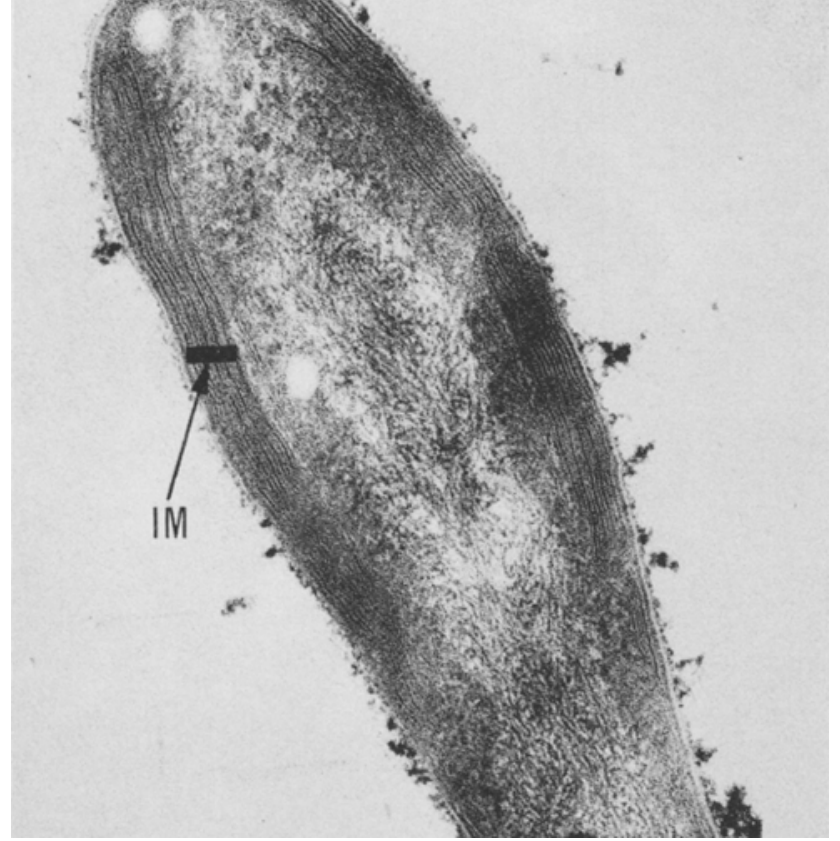

Figure 14. Thin section of the purple bacterium, Rhodopseudomonas palustris, showing the regular infoldings of the cell membrane (IM) which bears the photosynthetic apparatus. $120,000 \times$. Courtesy of Dr. Germaine Cohen-Bazire.

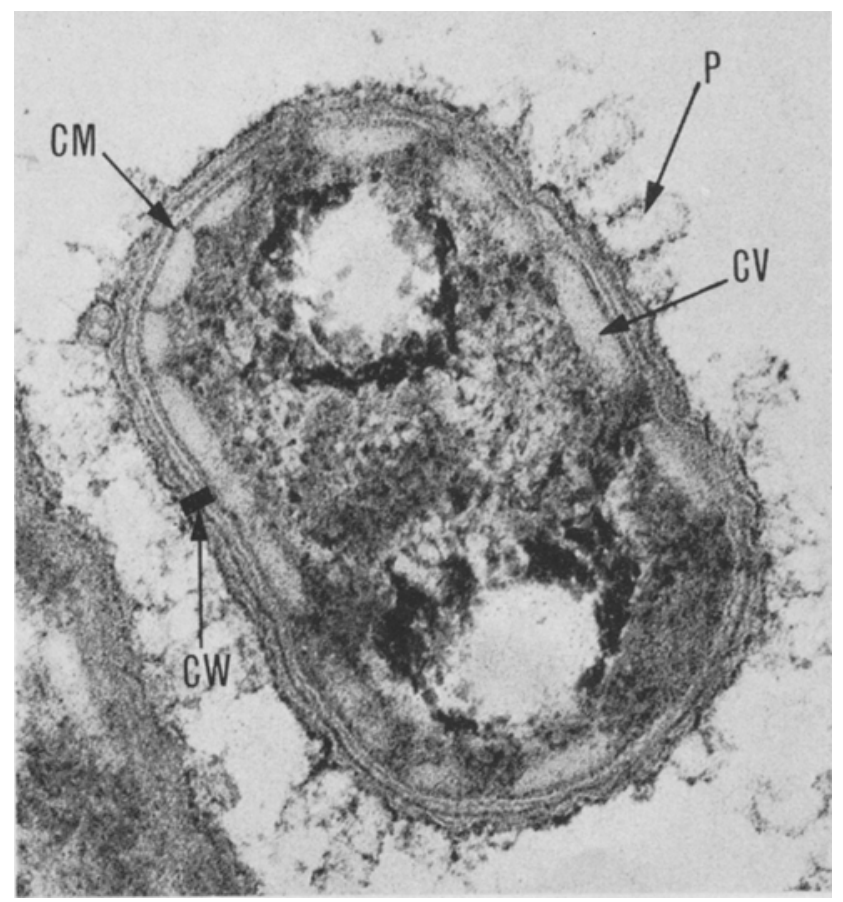




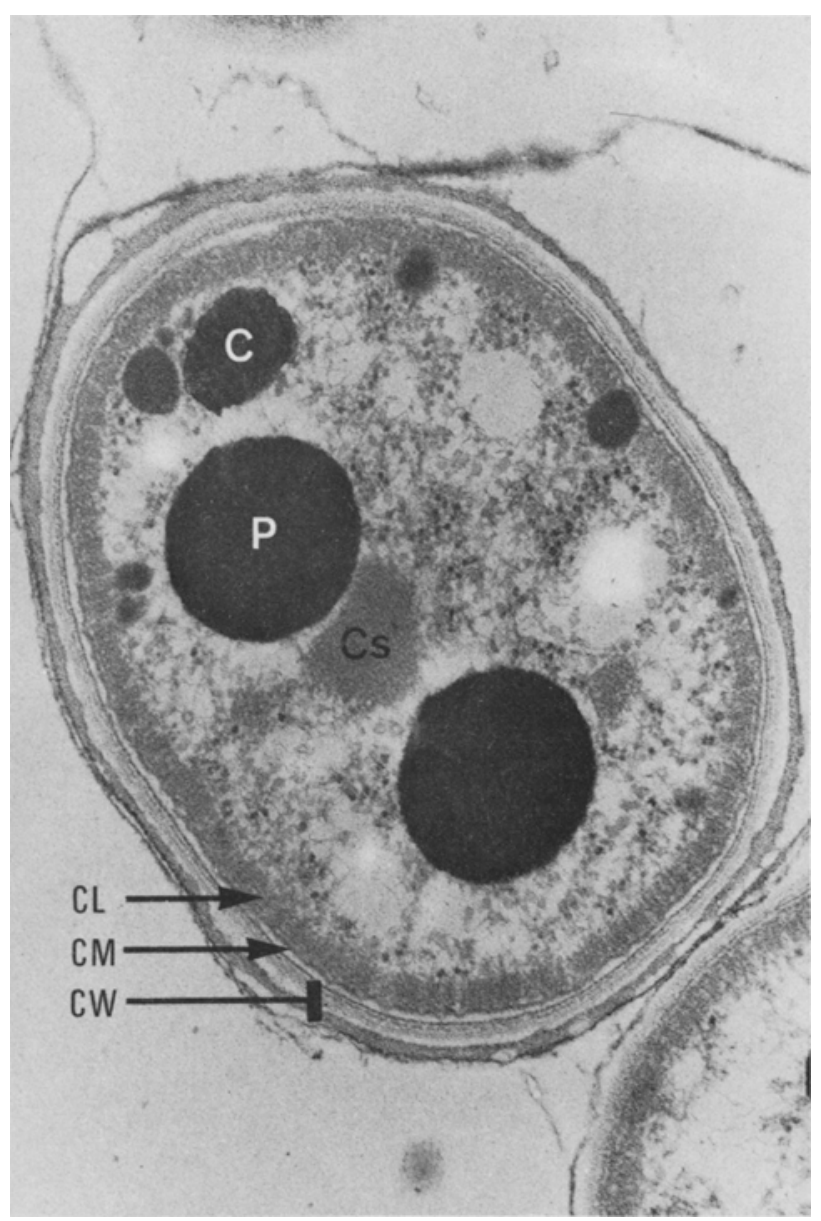

Figure 16. Thin section of a cyanobacterium without thylakoids, Gloeobacter violaceus A TCC 29082 . CW, cell wall. $\mathrm{CM}$, cell membrane. $\mathrm{CL}$, cortical layer of phycobiliproteins. P, polyphosphate granule. C, cyanophycin granule. Cs, carboxysome. 49,000 x. From (37).

16 and 17). In a unicellular cyanobacterium which we have recently described, Gloebacter violaceus (37), its structure is analogous to that in green bacteria. A cell membrane of simple topology is the site of the reaction centers and the electron transport system; the light-harvesting antenna of phycobiliproteins is located in a continuous subcortical layer, in contact with the inner surface of the cell membrane. The second configuration, characteristic of all other cyanobacteria so far studied, resembles that of the chloroplast: the photosynthetic appa- ratus has become internalized. An extensive system of flattened membranous sacs or thylakoids, topologically separated from the cell membrane, contains the reaction centers and the electron transport system. The light-harvesting antenna of phycobiliproteins is borne in a regular array of granules known as phycobilisomes, attached to the outer membrane surface of the thylakoids. In such cyanobacteria, the cell membrane probably does not contain any component of the photosynthetic machinery. In the red algal chloroplast (22), the phycobiliproteins also serve as major light-harvesting pigments, and the fine structure of the photosynthetic apparatus is homologous with that of most cyanobacteria. The various modes of organization of the photosynthetic apparatus are compared diagrammatically in fig. 18.

3.4. Physiological correlates of anoxygenic and oxygenic photosynthesis.

In purple and green bacteria, anoxygenic photosynthesis is associated with an anaerobic life style. The majority of these organisms are strict anacrobes. Some purple bacteria and one small group of green bacteria can tolerate molecular oxygen, and use it as a respiratory electron acceptor. However, even these organisms are unable to grow photosynthetically in the presence of air, as a result of the fact that bacteriochlorophyll synthesis is completely repressed by low partial pressures of oxygen (12).

The physiological properties of purple and green bacteria effectively confine them to illuminated, oxygen-free aquatic habitats (32). These reduced environments contain $\mathrm{H}_{2} \mathrm{~S}, \mathrm{H}_{2}$ and organic end-products formed by fermentative anaerobes, the nutrients required for photosynthetic growth of purple and green bacteria. Competition for solar energy with oxygenic phototrophs which inhabit the superficial aerobic water layer is not a problem, since the principal absorption bands in vivo of the bacteriochlorophylls are situated in the far red or infrared region, well beyond the spectral range used for oxygenic photosynthesis.

For cyanobacteria, as for eukaryotic phototrophs, the ability to grow photosynthetically in the presence of molecular oxygen is a physiological necessity. The cyanobacteria according- 


\section{R. Y. STANIER: Cyanobacteria}

ly belong to the physiologico-nutritional category of aerobic photoautotrophs. Their adaptation to an aerobic environment has several secondary expressions. Unlike many purple and green bacteria, cyanobacteria cannot generate ATP by fermentative means; their dark metabolism is purely respiratory. They also share with the great majority of algae the ability to use nitrate as a nitrogen source; no purple or green bacteria can perform an assimilatory reduction of nitrate.

\section{CYANOBACTERIAL CARBON METABOLISM AND THE PHENOMENON OF OBLIGATE PHOTOAUTOTROPHY}

Under photoautotrophic growth conditions, cyanobacteria assimilate $\mathrm{CO}_{2}$ through the reductive pentose phosphate cycle (30) and fixed carbon in excess of biosynthetic needs is stored as glycogen (fig. 19). In the dark, the endogenous glycogen reserve is mobilised and respired through the oxidative pentose phosphate cycle $(6,31)$, as shown in fig. 20 . The two dehydrogenases of this metabolic pathway, glucose-6phosphate and 6-phosphogluconate dehydrogenases, are both NADP-specific in cyanobacteria (31). Dark ATP synthesis is thus associated with the reoxidation of NADPH via an $\mathrm{O}_{2}$ - linked respiratory transport chain (3), the components of which have not so far been characterized. There is, accordingly, a very close interrelationship between the primary pathways of dark and light carbon metabolism in cyanobacteria (fig. 21).

A distinctive feature of the intermediary carbon metabolism of cyanobacteria is that the tricarboxylic acid cycle does not operate as a respiratory pathway (41). This reflects the absence of the enzyme $\alpha$-ketoglutarate dehydrogenase; levels of malic and succinic dehydrogenases are also very low (41). The role of the remaining enzymes normally associated with the tricarboxylic acid cycle is purely biosynthetic in cyanobacteria.

The nature of cyanobacterial carbon metabolism is reflected in the very limited heterotrophic capacity characteristic of these organisms

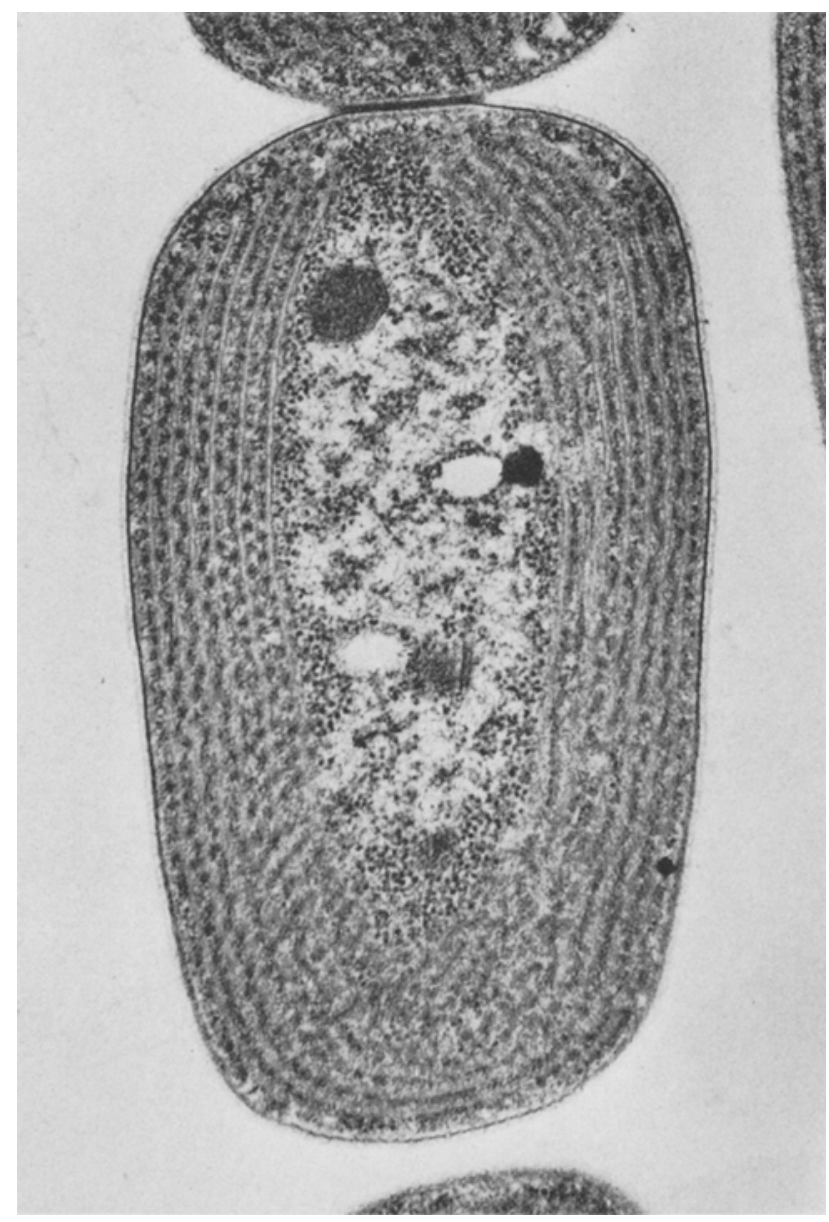

Figure 17. Thin section of a filamentous cyanobacterium of the Lyngbya-Plectonema-Phormidium group, ATCC 29344, with a cortical parallel array of thylakoids bearing phycobilisomes. $50,000 \mathrm{x}$.

(33). Many of them are obligate photoautotrophs; and even those species which can grow in the dark do so at the expense of a small range of organic substrates, all carbohydrates which can be metabolized through the oxidative pentose phosphate pathway (36). Dark growth of facultative heterotrophs is always much slower than photoautotrophic growth.

The utilizability of sugars as exogenous substrates is dependent on the possession by the cell of the appropriate permeases; and the absence of carbohydrate transport systems appears to account in large part, though perhaps not 
R. Y. STANIER: Cyanobacteria

LOCATION OF:

\begin{tabular}{|c|c|c|c|}
\hline$\frac{\text { PHOTOSYNTHETIC }}{\text { PROKARYOTES }}$ & PIGMENT ANTENNA & $\begin{array}{l}\text { REACTION } \\
\text { CENTER (S)AND } \\
\text { E.T.SYSTEM }\end{array}$ & SCHEMATIC DIAGRAM: \\
\hline Purple bacteria & Cell membrane & Cell membrane & $\begin{array}{l}\text { - c.w. } \\
\text { c.m. }\end{array}$ \\
\hline Green bocteria & Chlorobium vesicle & Cell membrane & $\begin{array}{l}-c . w . \\
= \\
= \\
\text { chmi. }\end{array}$ \\
\hline \multicolumn{4}{|l|}{ Cyanobacteria: } \\
\hline Gloeobacter & Subcortical layer & Cell membrone & . \\
\hline All others & Phycobilisome & Thylakoid membrane & $\begin{array}{l}\text { - c.w. } \\
\text { E c.m. } \\
\text { - thyl. }\end{array}$ \\
\hline \multicolumn{4}{|l|}{ CHLOROPLASTS } \\
\hline Rhodophyton & Phycobilisome & Thylakoid membrane & $\begin{array}{l}\text { Dosome } \\
\text { - thyl. }\end{array}$ \\
\hline Chiorophytan & Thylakoid membrane & Thylakoid membrane & $\begin{array}{l}\text { - chl. om. } \\
\text { - thyl. }\end{array}$ \\
\hline
\end{tabular}

\section{COMPARATIVE ANATOMY OF THE \\ PHOTOSYNTHETIC APPARATUS}

Figure 18. Comparative anatomy of the photosynthetic apparatus in prokaryotes and chloroplasts. CW, cell wall; $\mathrm{CM}$, cell membrane; chl. ves., chlorobium vesicle; subc. layer, phycobiliprotein-cortaining cortical layer; thyl, thylakoid; pbsome, phycobilisome; chl. om., chloroplast outer membrane.

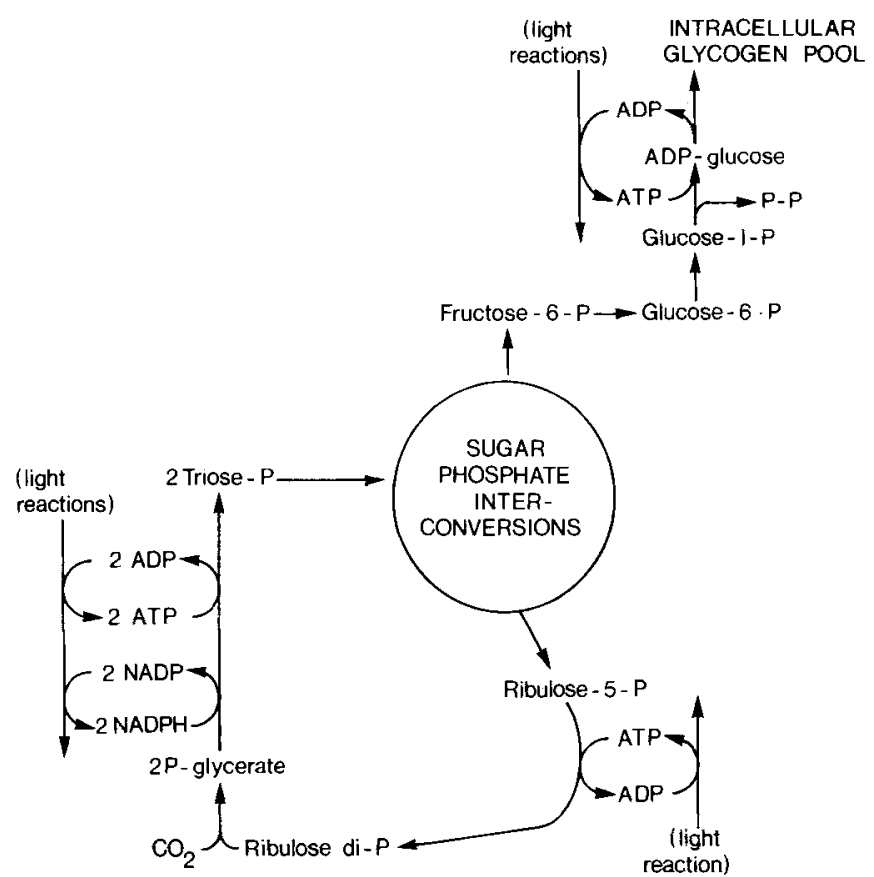

Figure 19. The primary paths of autotrophic carbon assimilation by cyanobacteria in the light. entirely, for the prevalence of obligate photoautotrophy among cyanobacteria (31). The active transport system which mediates glucose uptake by facultatively heterotrophic cyanobacteria has recently been characterized (2); it permits the intracellular concentration, as free sugars, of glucose and non-metabolizable glucose analogs.

\section{PHYSIOLOGICAL AND METABOLIC FACTORS THAT GOVERN THE NATURAL DISTRIBUTION OF CYANOBACTERIA}

The cyanobacteria are very highly specialized for a photoautotrophic mode of life, based on the performance of oxygenic photosynthesis. This brings them into direct competition in natural environments with eukaryotic algae, from which they do not differ significantly, as do purple and green bacteria, in the spectral properties of their light-harvesting pigments. Their competitive success is incontestable; no major group of algae has an ecological range as exten- 
sive and varied as that of cyanobacteria. To what do cyanobacteria owe their ability to find a place in the sun?

It is not attributable to intrinsically high photosynthetic growth rates, since the mean generation times in culture of most cyanobacteria range from $12-48 \mathrm{hr}$. and are thus considerably longer than those of many unicellular algae. Although this ecological question cannot be fully answered, the factors which lead to the predominance of cyanobacteria in some environments are now understood. They reflect, without exception, the possession by cyanobacteria of physiological or metabolic properties that are widely distributed among other prokaryotes, but wholly absent from eukaryotes.

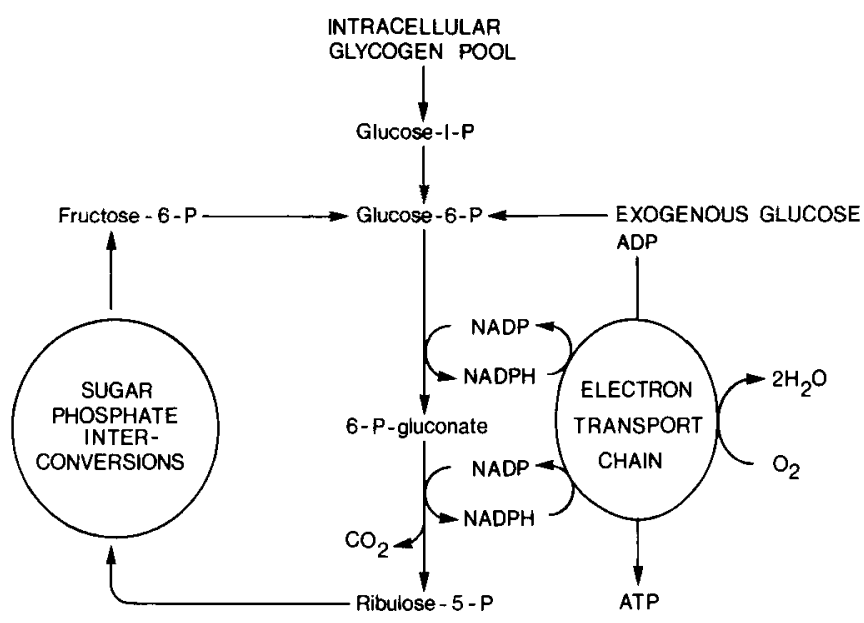

Figure 20. The pathways of cyanobacterial respiratory metabolism in the dark.

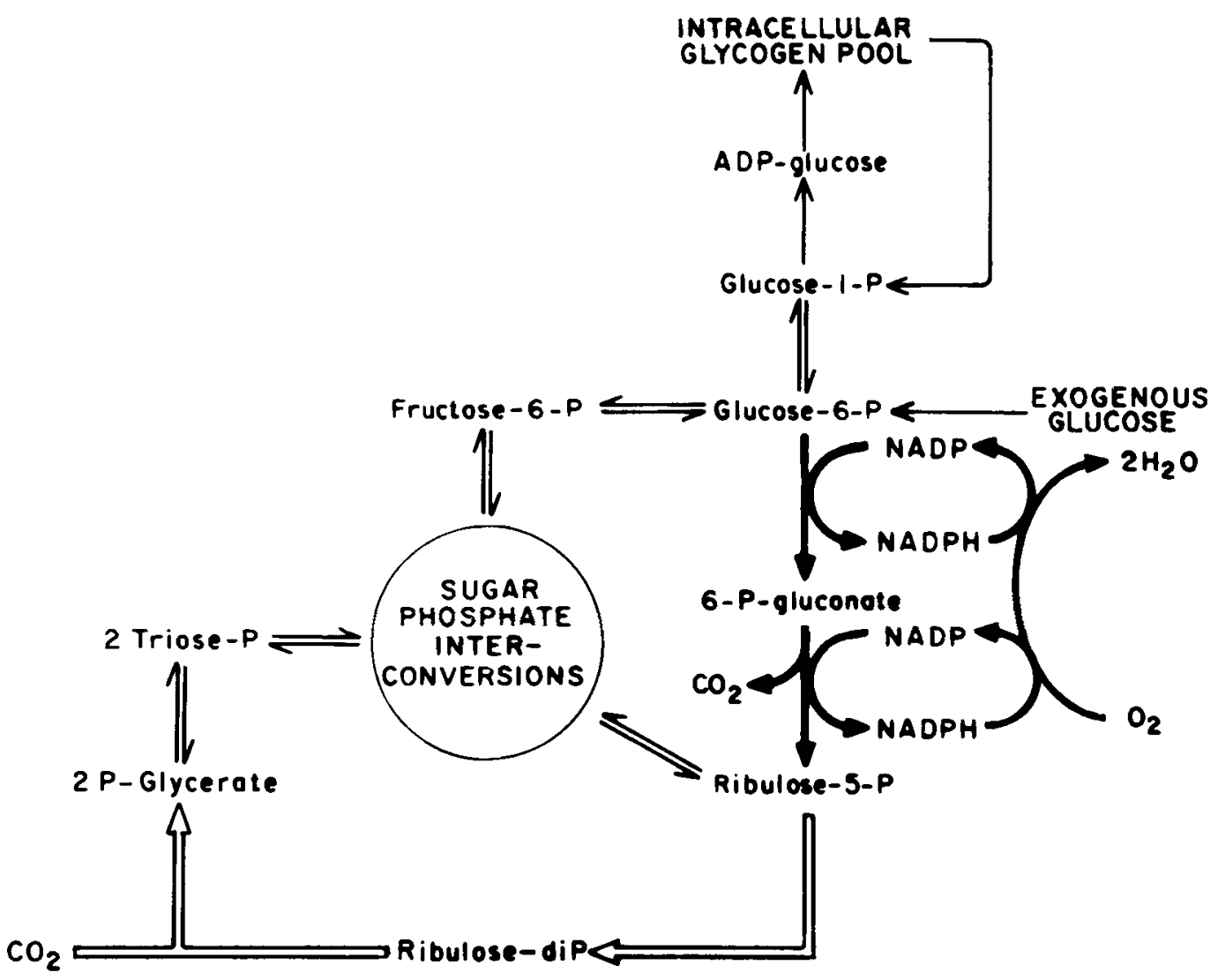

Figure 21. The interrelations between the primary photosynthetic and respiratory pathways of carbon metabolism in cyanobacteria. Heavy white arrows indicate step-reactions specific to light metabolism; heavy black arrows, those specific to dark metabolism. 


\subsection{Temperature relationships}

Certain cyanobacteria are thermophiles, with temperature maxima as high as $75^{\circ} \mathrm{C}(4,5)$. The upper temperature limit for growth of any phototrophic eukaryote lies at $55-60^{\circ} \mathrm{C}$ (14). As a result, cyanobacteria constitute the dominant, indeed almost the exclusive, photosynthetic population of hot springs. Thermotolerance appears to be the key factor which makes cyanobacteria the major agents of photosynthesis in deserts, where some of these organisms have found a remarkable ecological niche. They develop as a subsurface layer in desert rocks, in microfissures where water is trapped by condensation at night. The cyanobacteria from this habitat are thermoduric, but not thermophilic; their diurnal period of growth is consequently confined to the early morning, development being arrested by the rise of temperature during the day (19).

\subsection{Nitrogen fixation}

Many cyanobacteria can fix atmospheric nitrogen. This property is absent from all phototrophic eukaryotes, with the exception of the various plant groups which have entered into symbiotic relations with $\mathrm{N}_{2}$-fixing prokaryotes. Nitrogen-fixing cyanobacteria thus dominate the microbial phototrophic population in environments where the supply of combined nitrogen is limiting (49).

At first sight, oxygenic photosynthesis and nitrogen fixation appear to be incompatible metabolic processes, since nitrogenase, the enzyme which catalyzes the reduction of $\mathrm{N}_{2}$ to ammonia, is rapidly and irreversibly denatured by low partial pressures of oxygen (13). Yet all cyanobacteria which produce heterocysts are active aerobic nitrogen-fixers (48). For many decades, the heterocyst remained a biological enigma: it was a structurally specialized cell to which the botanists were unable to assign any clear-cut function (27). Through work in several laboratories, this puzzle has been largely solved during the past ten years.

Heterocyst formation is repressed, as a rule completely, in cultures grown with an excess of nitrate or ammonia. If such filaments of vegetative cells are transferred to a medium lacking a combined nitrogen source, from 5 to $10 \%$ of the cells become converted to heterocysts. The formation of mature heterocysts takes about 24 hours, and is paralleled by the development of nitrogenase activity (29). During differentiation, the poles of the heterocyst become drawn out; a small and structurally specialized contact area with the adjacent vegetative cells is formed. A complex outer envelope, greatly thickened and multilayered in the region of the cell-tocell junction, is laid down around the developing heterocyst (26). The mature heterocyst cannot divide or de-differentiate (53). It has lost photosystem II activity, but still retains photosystem I activity, and hence can perform cyclic photophosphorylation (15).

The structural and functional changes that accompany the development of the heterocyst confer on it the ability both to maintain nitrogenase in an active state, and to meet by photochemical means the large ATP requirement for the reduction of $\mathrm{N}_{2}$ to ammonia. However, the heterocyst, having lost the ability to assimilate $\mathrm{CO}_{2}$, can no longer synthesize the organic compounds required both as electron donors for the reduction of $\mathrm{N}_{2}$, and for the synthesis of organic nitrogenous compounds from ammonia. For these, the heterocyst is dependent on the intracellular transfer of organic metabolites formed through $\mathrm{CO}_{2}$ fixation in the neighboring vegetative cells (54). In turn, the vegetative cells obtain from the heterocyst their combined nitrogen supply. The form in which nitrogen is transferred from the heterocyst to the adjacent vegetative cells of the filament has been identified very recently as glutamine (28). Accordingly, in this large sub-group of cyanobacteria, the physiological incompatibility between nitrogen fixation and oxygenic photosynthesis has been circumvented by a cellular separation of the two activities, achieved through a unique type of cellular differentiation.

As recently as 1969, heterocystous cyanobacteria were the only cyanobacteria known to fix nitrogen. Aerobic nitrogen fixation, permitting photoautotrophic growth in a medium free of combined nitrogen, has since been demonstrated in a few unicellular cyanobacteria, all belonging to the genus Gloeothece $(55,34)$. These organisms must possess a mechanism which permits the maintenance of an active 
R. Y. StaNIER: Cyanobacteria

nitrogenase in vegetative cells which are engaged in the performance of oxygenic photosynthesis, but its physiological basis is not known.

In 1970, StewarT and LeX (50) showed that the oscillatorian cyanobacterium Plectonema can synthesize nitrogenase, even though it is incapable of growing aerobically at the expense of $\mathrm{N}_{2}$. By placing filaments in a nitrogen-free medium in the light under an anaerobic atmosphere, renewed at intervals, they were able to induce detectable nitrogenase activity. This activity rapidly disappeared when the filaments were exposed to air; the nitrogenase of Plectoma is thus oxygen-sensitive in vivo.

RIPPKA (35) has recently extended the search for non-heterocystous cyanobacteria able to synthesize nitrogenase, by the development of a technique which permits the synthesis of the enzyme in the complete absence of molecular oxygen. The cultures, grown with a combined nitrogen source, are pre-incubated aerobically, in the light in the presence of $\mathrm{CO}_{2}$, but in the absence of combined nitrogen. Under these conditions, since general biosynthesis is prevented by nitrogen starvation, the cells accumulate a massive glycogen reserve. The cultures are then placed under anaerobic conditions (argon-acetylene atmosphere) in the light, in the presence of $10^{-5} \mathrm{M} \mathrm{DCMU}$, which abolishes photosystem II activity and thus prevents endogenous oxygen production. Under these special conditions, strains which possess the necessary genetic information can both synthesize nitrogenase, and express its activity (measured by acetylene reduction). The cellular glycogen reserve provides a source of carbon and of reducing power; and ATP can be synthesized by cyclic photophosphorylation. Such experiments have shown that approximately half the oscillatorian and pleurocapsalean strains in our collection are potential nitrogenfixers, although none of them can maintain nitrogenase activity when exposed to air.

The widespread occurrence of the genetic information for nitrogen fixation among nonheterocystous cyanobacteria revealed by this survey is difficult to explain, unless the property can achieve effective phenotypic expression under natural conditions. However, the two major modes of cyanobacterial energy-yielding metabolism heretofore recognized - oxygenic photosynthesis and oxygen-linked respiration preclude the expression of the property by these cyanobacteria. As described below, this paradox has now been resolved.

\subsection{Facultative anoxygenic photosynthesis}

A mode of cyanobacterial photosynthesis which does not lead to oxygen production has been recently discovered by COHEN (7), as the outcome of a detailed ecological analysis of a shallow hypersaline lagoon, the Solar Lake, situated on the Gulf of Eilat. In the winter, stratification produces an anaerobic layer with a steep $\mathrm{H}_{2} \mathrm{~S}$ gradient, inhabited by three populations of photosynthetic prokaryotes. In the upper parts of the anaerobic layer, purple and green sulfur bacteria form two largely distinct horizontal layers. Oscillatorian cyanobacteria are present at all levels, but form a dense mat at the bottom, where the $\mathrm{H}_{2} \mathrm{~S}$ concentration is maximal. This is a complete reversal of the usual situation in a stratified lake, where oxygenic phototrophs normally occur in the aerobic surface layer. Cohen accordingly suspected that the cyanobacteria in this particular ecosystem might be engaged in anoxygenic photosynthesis, a hypothesis confirmed by isolating the predominant species, Oscillatorian limnetica, and studying its physiological properties (8). Like all other cyanobacteria, this organism can develop as an oxygenic photoautotroph. Exposure of filaments to a concentration of $4 \mathrm{mM}-\mathrm{H}_{2} \mathrm{~S}$ totally inhibits photosystem II activity, and immediately arrests $\mathrm{CO}_{2}$ assimilation. However, after a short lag, the assimilation of $\mathrm{CO}_{2}$ is resumed, now accompanied by a stoichiometric oxidation of $\mathrm{H}_{2} \mathrm{~S}$ to elemental sulfur, which is deposited outside the filament. Since this occurs even in the presence of DCMU, it cannot be attributed to a resumption of photosystem II activity. Sulfide evidently has two effects on the metabolism of this organism, one immediate and one delayed. The immediate effect is to act as a selective inhibitor of photosystem II, converting the photosynthetic machinery into a phenocopy of the purple or green bacterial one. The delayed effect is the induction of a sulfide-oxidizing enzyme system, 
which makes possible the resumption of photosynthetic $\mathrm{CO}_{2}$ assimilation. The same group has since found (23) that several other non-heterocystous cyanobacteria respond similarly to sulfide, although the sulfide concentrations which permit anoxygenic photosynthesis are considerably lower than those tolerated by Oscillatoria limnetica.

This important discovery clarifies certain hitherto completely obscure aspects of cyanobacterial ecology. Many illuminated natural microenvironments either fluctuate periodically between the aerobic and anaerobic states, or are situated on a sharp boundary line between the oxygenated and the anaerobic, sulfide-rich regions of the biosphere; and oscillatorian cyanobacteria are frequently abundant in these habitats (for example, muddy areas in the intertidal zone). The ability to alternate readily between the performance of oxygenic and anoxygenic, sulfide-dependent photosynthesis, a metabolic capacity confined to cyanobacteria, confers a unique advantage in such micro-environments. The aerobic facet is closed to purple and green bacteria, while the anaerobic sulfide-rich facet is closed to eukaryotic alagae. Moreover, when growing in the anaerobic facet, cyanobacteria which do not produce heterocysts can express the genetic capacity to fix nitrogen. In this type of micro-environment, oscillatorian cyanobacteria may well play an important and hitherto unsuspected role as agents of nitrogen fixation.

\section{CONCLUDING REMARKS}

As E. C. HANSEN showed almost a century ago, many useful insights into problems of microbial ecology can be derived from experimental studies on pure cultures, performed under controlled conditions. The development of research on cyanobacteria, following the very tardy application to these organisms of pure methodology, provides a most instructive illustration of Hansen's working principle. In the past ten years, we have at last begun to understand the physiological and metabolic factors which account for the exceptionally wide natural distribution of the cyanobacteria, and which had very largely escaped previous detection, when ecological studies were based on a purely descriptive analysis of field populations.

\section{REFERENCES}

1. Allen, M. B.: The cultivation of Myxophyceae. Arch. Mikrobiol. 17, 34-53 (1952)

2. Beauclerk, A. A. D. \& A. J. Smith: Carbohydrate uptake by cyanobacteria. Abstr. 2nd International Symposium on Photosynthetic Prokaryotes Aug. 1976. University of Dundee, Scotland (in press)

3. BIGGINS, J.: Respiration in blue-green algae. J. Bact. 99, 570-575 (1969)

4. Castenholz, R. W. : The thermophilic cyanophytes of Iceland and the upper temperature limit. J. Phycol. 5, 360-368 (1969a)

5. Castenholz, R. W.: Thermophilic blue-green algae and the thermal environment. Bact. Rev. 33, 476-504 (1969b)

6. Cheung, W. Y. \& M. Gibas: Dark and photometabolism of sugars by a blue green algae Tolypothrix tenuis. Plant Physiol. 41, 731-737 (1966)

7. CoHen, Y.: Dynamics of prokaryotic photosynthetic communities of the Solar Lake. Thesis, Hebrew University, Jerusalem (1975)

8. Cohen, Y., E. Padan \& M. Shilo: Facultative anoxygenic photosynthesis in the cyanobacterium Oscillatoria limnetica. J. Bact. 123, 855-861 (1975)

9. Cohen-Bazire, G: The photosynthetic apparatus of prokaryotic organisms. In Biological Ultrastructure: The Origin of Cell Organelles . Harris, P. J. ed., 30th Annual Biology Colloquium, Oregon state University Press, U. S. A., pp. 65-90 (1971)

10. Cohen-Bazire, G. \& R. Kunisawa: The fine structure of Rhodospirillum rubrum. J. Cell Biol. $16,401-419(1963)$

11. Cohen-Bazire, G., N. Pfennig \& R. Kunisawa: The fine structure of green bacteria. J. Cell Biol. 22, 207-225 (1964)

12. Cohen-Bazire, W. R. Sistrom \& R. Y. Stanier: Kinetic studies of pigment synthesis by non-sulfur purple bacteria. J. Cell Comp. Physiol. 49, 25-68 (1957)

13. Dalton, H. \& L. E. MoRtenson: Dinitrogen $\left(\mathrm{N}_{2}\right)$ fixation (with a biochemical emphasis). Bact. Rev. 36, 231-260 (1972)

14. Doemel, W. N. \& T. D. Brock: The upper temperature limit of Cyanidium caldarium. Arch. Mikrobiol. 72, 326-332 (1970) 
15. Donze, M., J. Haveman \& P. Schiereck: Absence of photosystem 2 in heterocysts of the blue-green alga Anabaena. Biochim. Biophys. Acta 256, 157-161 (1972)

16. DREwS, G.: Fine structure and chemical composition of the cell envelopes. In ,The Biology of Blue-green Algaeu. Carr, N. G. and B. A. Whitton, eds., Blackwell, Oxford. pp. 99-116 (1973)

17. FoGG, G. E.: Growth and heterocyst production in Anabaena cylindrica Lemm. II. In relation to carbon and nitrogen metabolism. Ann. Bot., N. S. 13, 241-359 (1949)

18. Frank, H., M. Lefort \& H. H. Martin: Elektronenoptische und chemische Untersuchungen an Zellwänden der Blaualgen, Phormidium uncinatum. Z. Naturf. B. 17, 262-268 (1962)

19. Friedmann, I., Y. Lipkin \& R. OCampo-paus: Desert algae of the Negev (Israel). Phycologia 6, $185-200$ (1967)

20. FULler, R. C. \& C. BOYCE: The association of the photochemical reaction centre and the cytoplasmic membrane of the green bacteria. Abstr. 2nd International Symposium on Photosynthetic Prokaryotes Aug. 1976. University of Dundee, Scotland (in press)

21. GANTT, E. \& S. F. ConTI: Ultrastructure of bluegreen algae. J. Bact. 97, 1486-1493 (1969)

22. GanNT, E. \& S. F. Contr: Granules associated with the chloroplast lamellae of Porphyridium cruentum. J. Cell Biol. 29, 423-434 (1966a)

23. Garlick, S., A. Oren \& E. Padan: Occurrence of facultative anoxygenic photosynthesis among filamentous and unicellular cyanobacteria. $J$. Bact. 129 (2) (in press)

24. Halfen, L. N. \& R. W. Castenholz: Gliding in a blue-green alga: a possible mechanism. Nature 225, 1163-1165(1970)

25. Krogmann, D.: Photosynthetic reactions and components of thylakoids. In $n$ The Biology of Blue-green Algaex. Carr, N. G. and B. A. Whitton, eds., Blackwell, Oxford. pp. 80-98 (1973)

26. LANG, N. J. \& P. FAY: The heterocysts of bluegreen algae. II. Details of ultrastructure. Proc. R. Soc. B., 193-203 (1971)

27. Lang, N. J., R. D. Simon \& C. P. Wolk: Correspondence of cyanophycin granules with structured granules in Anabaena cylindrica. Arch. Mikrobiol. 83, 313-320(1972)

28. Meeks, J. C. \& C. P. Wolk: Glutamine formation by heterocysts of Anabaena cylindrica. Abstr. 2nd International Symposium Photosynthetic Prokaryotes Aug. 1976. University of Dundee, Scotland (in press)

29. Neilson, A., R. RippKa \& R. Kunisawa: Heterocyst formation and nitrogenase synthesis in
Anabaena spp.: a kinetic study. Arch. Mikrobiol. 76, 139-150(1971)

30. Pelroy, R. A. \& J. A. Bassham: Photosynthetic and dark carbon metabolism in unicellular bluegreen algae. Arch. Mikrobiol. 86, 25-38 (1972)

31. Pelroy, R. A., R. Ruppxa \& R. Y. Stanier: The metabolism of glucose by unicellular blue-green algae. Arch. Mikrobiol. 87, 303-322 (1972)

32. Pfennig, N.: Photosynthetic bacteria. Ann. Rev. Microbiol. 21, 285-324 (1967)

33. RIPPKA, R.: Photoheterotrophy and chemoheterotrophy among unicellular blue-green algae. Arch. Mikrobiol. 87, 93-98 (1972)

34. Rippka, R., A. Nielson, R. Kunisawa \& G. COHEN-BAZIRE: Nitrogen fixation by unicellular blue-green algae. Arch. Mikrobiol. 76, 341-348 (1971)

35. RipPKa, R. \& R. Y. StanieR: Nitrogenase synthesis by cyanobacteria under conditions of strict anaerobiosis. Abstr. 2nd International Symposium on Photosynthetic prokaryotes Aug. 1976. University of Dundee, Scotland (in press)

36. RipPKa, R. \& R. Y. STANIER: Photoheterotrophy and chemoheterotrophy in blue-green algae. Abstr. International Symposium on Photosynthetic Prokaryotes, Freiburg i. Br., pp. 135-138 (1973)

37. RippKa, R., J. Waterbury \& G. Cohen-Bazire: A cyanobacterium which lacks thylakoids. Arch. Mikrobiol. 100, 419-436(1974)

38. Shively, J. M., F. Ball, D. H. Brown \& R. E. SAUNDERS: Functional organelles in prokaryotes: polyhedral inclusions (carboxysomes) of Thiobacillus neapolitanus. Science 182, 584-586 (1973)

39. Simon, R. D.: Cyanophycin granules from the blue-green alga Anabaena cylindrica: a reserve material consisting of copolymers of aspartic acid and arginine. Proc. Nat. Acad. Sci. U. S. A. 68, 265-267 (1971)

40. Simon, R. D. \& P. Weathers: Determination of the structure of the novel polypeptide containing aspartic acid and arginine which is found in cyanobacteria. Biochim. Biophys. Acta 420 , 165-186 (1976)

41. Smith, A. J., J. London \& R. Y. Stanier: Biochemical basis of obligate autotrophy in bluegreen algae and thiobacilli. J. Bact. 94, 972-983 (1967)

42. Stanier, R. Y.: Photosynthetic mechanisms in bacteria and plants: development of a unitary concept. Bact. Rev. 25, 1-17 (1961)

43. Stanier, R. Y.: Some aspects of the biology of cells and their possible evolutionary significance. In "Organization and Control in Prokaryotic and Eukaryotic Cellsk. Charles, M. P. And B. C. 
Knight, eds., 20th Symposium Soc. gen. Microbiol., (457 pp.), Cambridge U. P., England. pp 1-38 (1970)

44. Stanter, R. Y., E. A. Adelberg \& J. L. IngraHAM: "The Microbial Worldk, 4th edn., Prentice-Hall, Englewood Cliffs, U. S. A. (1976)

45. Stanier, R. Y., M. Doudoroff, R. Kunisawa \& $R$. Contopoulou: The role of organic substrates in bacterial photosynthesis. Proc. Nat. Acad. Sci. 45, 1246-1260 (1959)

46. Stanier, R. Y. \& C. B. van Niel: The concept of a bacterium. Arch. Mikrobiol. 42, 17-35 (1962)

47. Stanier, R. Y., R. Kunisawa, M. Mandel \& G. Cohen-Bazire: Purification and properties of unicellular blue-green algae (Order Chroococcales). Bact. Rev. 35, 171-205 (1971)

48. Stewart, W. D. P.: Biological and ecological aspects of nitrogen fixation by free-living microorganisms. Proc. R. Soc. B. 172, 367-388 (1969)

49. Stewart, W. D. P.: Nitrogen fixation. In "The Biology of Blue-green Algaex. Carr, N. G. and B.
A. Whitton, eds., Blackwell, Oxford. pp. 260-278 (1973)

50. Stewart, W. D. P. \& M. Lex: Nitrogenase activity in the blue-green alga Plectonema boryanum strain 594. Arch. Mikrobiol. 73, 250-260 (1970)

51. Waterbury, J. D. \& R. Y. Stanier: Two unicellular cyanobacteria which reproduce by budding. Arch. Mikrobiol. (in press)

52. Waterbury, J. D. \& R. Y. Stanier: Purification and properties of some cyanobacteria belonging to the order Pleurocapsales. Bact. Rev. (in press)

53. Willcox, M., G. J. Mrtchison \& R. J. Smith: Pattern formation in the blue-green alga Anabaena. II. Controlled proheterocyst regression. J. Cell Sci. 13, 637-649 (1973)

54. WYATT, J. J. \& J. K. G. SILVEY: Nitrogen fixation by Gloeocapsa. Science 165, 908-909 (1969)

55. Wolk, C. P.: Movement of carbon from vegetative cells to heterocysts in Anabaena cylindrica. J. Bact. 96, 2138-2143 (1968) 